\title{
MORPHOMETRIC STUDY OF PLACENTA IN RELATION TO BIRTH WEIGHT OF FULL TERM NEWBORNS
}

\section{Divya Shanthi D'Sa ${ }^{1}$, Sangeetha V 2 .}

${ }^{1}$ Assistant Professor, Subbaiah Institute of Medical Sciences, Shimoga, Karnataka, India.

${ }^{* 2}$ Assistant Professor, Subbaiah Institute of Medical Sciences, Shimoga, Karnataka, India.

\section{ABSTRACT}

Background: Placenta is a functional unit between the mother and the fetus. It is the discoid, deciduate, haemochorial, chorioallantoic, endocrine gland which connects developing embryo by umbilical cord to the uterus. It develops from two sources. The fetal component which is the principal component develops from chorion frondosum and the maternal component from decidua basalis. If the decidual part of the placenta is healthy, the embryogenesis from germinal period up to the end of fetal period will be healthy. Otherwise it will lead to anomalies of the placenta, umbilical cord and of the fetus including low birth weight. There is a proven direct relationship between placental growth, fetal well-being and finally fetal outcome.

Aim: To study the morphometry of placenta in relation to birth weight of full term newborns.

Methodology: For the study, 60 discarded placentae were collected at random from deliveries (both vaginal and caesarian) conducted at the teaching hospital of Subbaiah Institute of Medical Sciences. Thirty out of the sixty placentae were from controls (birth weight $>2500 \mathrm{gms}$ ) and thirty from low birth weight deliveries (birth weight $<2500 \mathrm{gms})$. In the collected placenta, the weight, volume, diameter and thickness of placenta were measured. The foeto-placental ratio and placental co-efficient was calculated.

Results: Our study demonstrated a significant relationship between placental morphometry and birth weight. Conclusion: Because of the growing evidence of correlation of placental morphology with chronic diseases in later life, we suggest examination of placenta at the time of birth.

KEY WORDS: Birth weight, Placenta, Placental morphometry.

Address for Correspondence: Dr. Sangeetha V, Assistant Professor, Department of Anatomy, Subbaiah Institute of Medical Sciences, NH-13, Purle, HH Road, Shimoga: 577222, Karnataka, India. Mobile no: 9481831659 E-Mail: sanman77@rediffmail.com

Access this Article online

Quick Response code

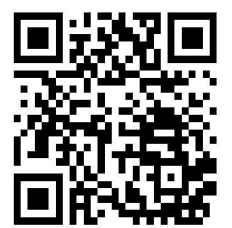

DOI: $10.16965 /$ ijar.2017.508

Journal Information

International Journal of Anatomy and Research

ICV for 2016
90.30

ISSN (E) 2321-4287 | ISSN (P) 2321-8967

https://www.ijmhr.org/ijar.htm

DOI-Prefix: https://dx.doi.org/10.16965/ijar

Article Information

Received: 15 Nov 2017

Peer Review: 15 Nov 2017

Revised: None
Accepted: 02 Jan 2018

Published (O): 05 Feb 2018

Published (P): 05 Feb 2018

\section{INTRODUCTION}

Placenta is a functional unit between the mother and the foetus. Only eutherian mammals possess placenta. Human placenta is discoid, deciduate, haemochorial, chorioallantoic, labyrinthine and endocrine gland which connects developing embryo by umbilical cord to the endometrium of mother's uterus. It develops from two sources. The fetal component which is the principal component develops from chorion frondosum and the maternal component from decidua basalis. The fetal surface is smooth, covered by amnion and presents the attachment of the umbilical cord close to its centre. The maternal surface is rough, irregular and spongy and is mapped out into 15-20 convex polygonal areas known as lobes or cotyledons which are limited by fissures [1]. 
The peripheral margin is continuous with the foetal membrane which consists from outside inwards of fused deciduas parietalis and capsularis, chorion laeve and amnion [2]. The placenta is usually attached to the upper part of the body of the uterus encroaching to the fundus adjacent to the anterior or posterior wall with equal frequency. Placenta separates after the birth of the baby and the line of separation is through the decidua spongiosum.

In the first trimester, growth of the placenta is more rapid than of the foetus, but by 17 weeks, placental and fetal weights are approximately equal. It occupies $30 \%$ of uterine wall. At term the placental weight is approximately $1 / 6^{\text {th }}$ of the fetal weight. At full term placenta presents the following measurements [2]:

Diameter: 15 to $20 \mathrm{~cm}$

Thickness: $3 \mathrm{~cm}$ (at the centre)

Weight: 500 gms

Proportional weight between placenta and foetus at various stages of pregnancy:

$1^{\text {st }}$ month: placenta: foetus $=6: 1$

$4^{\text {th }}$ month: placenta: foetus $=1: 1$

At birth: placenta: foetus $=1: 7$

If the decidual part of the placenta is healthy, the embryogenesis from germinal period up to the end of fetal period will be healthy. There is a proven direct relationship between placental growth, fetal well-being and finally fetal outcome. Hence the present study was conducted.

\section{MATERIALS AND METHODS}

For the study, 60 discarded placentae were collected at random from deliveries (both vaginal and caesarian) conducted at the teaching hospital of Subbaiah Institute of Medical Sciences. Thirty out of the sixty placentae were from controls (birth weight $>2500 \mathrm{gms}$ ) and thirty from low birth weight deliveries (birth weight $<2500$ gms).

In the collected placenta, the weight, volume, diameter and thickness of placenta were measured. The foeto-placental ratio and the placental co-efficient was calculated.

The cases were studied dividing into two experimental groups.

Group A - 30 placentae from deliveries of birth weight $\geq 2500 \mathrm{gm}$

Group B - 30 placentae from low birth weight deliveries (<2500gm).

The placenta with attached membranes and umbilical cord was collected soon after delivery washed in running tap water to clean all blood. Each specimen was tagged with number before commencement of the study, for the purpose of identity. In the collected placenta the following parameters were studied on gross examination:

Weight: Measured using electronic weighing machine.

Diameter: The placenta was placed in a flat tray after trimming. At first, the maximum diameter was measured with a metallic scale graduated in centimetres. Then the second maximum diameter was taken at right angles to the first one. The mean of the two measurements is considered to be the diameter of the placenta expressed in centimetres.

Thickness: Thickness of placenta was measured by piercing a needle through the centre of placenta. Then the needle was measured on the scale which gave the thickness of the placenta.

Volume: The volume of placenta was measured by weight displacement. The placenta was dipped in a container filled with water and the volume of water displaced was measured and was taken as the volume of placenta.

\section{The feto-placental ratio:}

The feto-placental ratio was calculated by dividing the weight of the foetus by weight of the placenta.

The placental coefficient: Placental co-efficient was calculated by dividing placental weight by birth weight.

\section{OBSERVATION AND RESULTS}

The present study was done with 60 placentae which was equally distributed between two groups, group A which included placentae of normal birth weight newborns and group B which included placentae of low birth weight newborns. (Table 1) The placental weight and volume in relation to the birth weight of the full term newborns has been tabulated in table 2 . The statistical results of the study have been tabulated in table 3 . 
Table 1: Number of cases.

\begin{tabular}{|c|c|}
\hline Groups & Total no. of cases \\
\hline $\begin{array}{c}\text { Group A (Placentae of } \\
\text { normal birth weight) }\end{array}$ & 30 \\
\hline $\begin{array}{c}\text { Group B (Placentae of low } \\
\text { birth weight <2500g) }\end{array}$ & 30 \\
\hline TOTAL & 60 \\
\hline
\end{tabular}

Table 2: Relation of birth weight with placental weight and volume.

\begin{tabular}{|c|c|c|c|c|c|c|c|}
\hline \multicolumn{2}{|c|}{ Parameters } & \multicolumn{2}{|c|}{$\begin{array}{l}\text { GROUPA (Placentae of } \\
\text { normal birth weight) }\end{array}$} & \multicolumn{2}{|c|}{$\begin{array}{l}\text { GROUP B (Placentae of low } \\
\text { birth weight < } 2500 \mathrm{~g} \text { ) }\end{array}$} & \multicolumn{2}{|r|}{ Total } \\
\hline & & No. & Percentage (\%) & №. & & №. & Percentage (\%) \\
\hline \multirow{3}{*}{$\begin{array}{l}\text { Weight of placent } \\
\text { (gms) }\end{array}$} & $<400$ & 0 & 0 & 17 & 56.66 & 17 & 28.33 \\
\hline & $400-500$ & 23 & 76.66 & 13 & 43.33 & 36 & 60 \\
\hline & $>500$ & 7 & 23.33 & 0 & 0 & 7 & 11.66 \\
\hline \multirow{3}{*}{$\begin{array}{l}\text { Volume of } \\
\text { placenta(ml) }\end{array}$} & $\leq 400$ & 9 & 30 & 25 & 83.33 & 34 & 56.66 \\
\hline & 401-499 & 12 & 40 & 4 & 13.33 & 16 & 26.66 \\
\hline & $\geq 500$ & 9 & 30 & 1 & 3.33 & 10 & 16.66 \\
\hline
\end{tabular}

Table 3: Comparison of mean of various variables.

\begin{tabular}{|c|c|c|c|c|c|}
\hline \multirow[t]{2}{*}{ Variable } & \multicolumn{2}{|c|}{$\begin{array}{l}\text { Group A (Placentas of } \\
\text { normal birth weight ) }\end{array}$} & \multicolumn{2}{|c|}{$\begin{array}{c}\text { Group B (Placentas of low } \\
\text { birth weight }<2500 \mathrm{~g} \text { ) }\end{array}$} & \multirow[t]{2}{*}{$\mathrm{p}$ Value } \\
\hline & Mean & SD & Mean & SD & \\
\hline Birth weight & 2963.33 & 230.04 & 1991.67 & 383.07 & $<0.001^{* *}$ \\
\hline Placental weight & 479.85 & 32.37 & 385.1 & 59.86 & $<0.001^{* *}$ \\
\hline Placental volume & 448.5 & 41.21 & 370.17 & 48.95 & $<0.001^{* *}$ \\
\hline Placental diameter & 18.88 & 0.95 & 16.67 & 2.13 & $<0.001^{* *}$ \\
\hline Placental thickness & 1.82 & 0.25 & 1.75 & 0.3 & $<0.001^{* *}$ \\
\hline Placental coefficient & 0.162 & 0.011 & 0.197 & 0.028 & $<0.001^{* *}$ \\
\hline Feto-placental ratio & 6.19 & 0.43 & 5.17 & 0.76 & $<0.001^{* *}$ \\
\hline
\end{tabular}

\section{DISCUSSION}

Placenta is a functional unit between the mother and the foetus. In the past the mother was the patient to be cared for, and the foetus was merely a maternal appendage. The evolution of the concept of the foetus as a patient has occurred rapidly over the last few decades. The growth and survival of the foetus in utero is directly related to formation, development and maturation of the placenta. The placenta is a complex fetal organ that fulfills pleiotropic roles during fetal growth.

The etiology of low birth weight is multi-factorial; with genetic, placental, fetal and maternal factors interplaying with each other. Despite the observed link between maternal health, placenta and newborn health, any kind of placental study is not routinely performed in hospitals. However a study focused at least on the placenta of low birth weight babies will shed light on the causative factors and will help in the better understanding of the etiology. Hence the present study is undertaken to analyze the spectrum of morphometric changes in placenta and its relation with birth weight of full term newborns. In the present study the mean placental weight was $479.85 \pm 32.37 \mathrm{gms}$ in normal birth weight group and $385.10 \pm 59.86$ gms in the low birth weight group and was found to be statistically significant. Placental weight and thickness has been taken as an indicator of placental function. Surya Babu et al studied 50 placentae of low birth weight babies and found that the placental parameters like weight and size of the placenta were significantly less than normal in low birth weight deliveries [3].

In a larger population size from Mexico (n: 300 live newborns) Sanin established a model to relate birth weight with placental weight [4]. Placental weight was found to be significantly related to birth weight. For each gram increase of weight of placenta, the birth weight increased by 1.98 gms $(p<0.01)$. The placenta however was shown to have a nonlinear relation to birth weight and could be used as a useful non-invasive predictor of birth weight.

The mean placental diameter in the present study was $18.88 \pm 0.95 \mathrm{~cm}$ in normal birth weight group and $16.67 \pm 2.13 \mathrm{~cm}$ in the low birth weight group. It was found to be statistically significant. According to a study by Habib FA a "warning limit" of a placental diameter of $18 \mathrm{~cm}$ and placental thickness of $2 \mathrm{~cm}$ at 36 weeks gestation were calculated to predict low birth weight infants [5].

The mean placental thickness in the present study was $1.82 \pm 0.25 \mathrm{~cm}$ in normal birth weight group and $1.75 \pm 0.30 \mathrm{~cm}$ in the low birth weight group. It was found to be statistically significant. The mean thickness of term placenta reported by Gunapriya et al., was $2.1 \mathrm{~cm}$, in other study by Hatti AM it was $2.21 \mathrm{~cm}$ whereas, in the study of Rupa L Balihallimath et al. the mean placental thickness was $2.1 \mathrm{~cm}$, 5th and 95th percentiles of placental thickness varied from 1.5 to $3.0 \mathrm{~cm}$, with no significant relationship with birth weight [6-8].

In the present study, the mean placental volume in the normal birth weight group was $448.50 \pm$ $41.21 \mathrm{ml}$ and in the low birth weight group it was $370 \pm 48.95 \mathrm{ml}$ which was statistically significant. 
In the study by Rupa L Balihallimath et al., the mean placental volume was $366.08 \pm 1.10 \mathrm{ml}$, with a significant positive correlation between the weight of the baby and the placental volume $(r=0.662 \mathrm{ml} ; p<0.001) .{ }^{8}$ This result is consistent with the other studies $[9,10]$.

In a study by R.D. Virupaxi et al. morphometric parameters of placenta like weight and volume were significantly lower in small for gestational age group babies as compared to full term normal group babies, these values were statistically significant $(p<0.0001)$ [11].

Foeto-placental ratio is the ratio of fetal weight to placental weight. The normal ratio is $1: 7$. The mean foeto-placental ratio in normal birth weight group was 6.19 whereas in low birth weight group, it was 5.17. The difference between two groups was statistically significant $(p<0.001)$.

Placental coefficient is defined as the ratio of placental weight to fetal weight. Normally it is 0.10 to 0.18 [12]. This correlated well with the present study. In the present study the placental co-efficient in normal birth weight group was $0.162 \pm 0.011$ and in low birth weight group was $0.197 \pm 0.028$. The placental co-efficient falls as the placental weight increases and high placental co-efficient is seen if the placental weight decreases. Placental coefficient outside the normal range is shown to be associated with perinatal adverse effects [12].

\section{CONCLUSION}

In the present study the placental morphometry was found to be significantly associated with low birth weight. The morphometric parameters like placental weight, volume, thickness and diameter was significantly less among the low birth weight newborns compared to normal birth weight.

The growth of the foetus during intrauterine life is reflected in the birth weight. Fetal growth is largely determined by the availability of nutrients from the mother, as well as placental capacity to supply these nutrients in sufficient quantities to the foetus. Placenta is essential for normal fetal development and failure of the placenta can result in fetal problems. Because of growing evidence for a correlation of placental weight and other placental parameters with chronic diseases in later life, we suggest attention and correct examination of placenta at the time of birth and recording all of the observations in patients' files as an important evidence for future. With evaluation and follow up of placenta growth in early pregnancy, we can prevent the risks for fetal life and improve infant health.

\section{Conflicts of Interests: None}

\section{REFERENCES}

[1]. Dutta D.C. The placenta and fetal membranes. Text book of obstetrics, $7^{\text {th }}$ edition. Kolkata: Central; 2011.p.28-40.

[2]. Dutta A.K. The placenta. Essentials of human embryology, $5^{\text {th }}$ edition. Kolkata: Current books international; p.58-68.

[3]. Surya Babu Sunkesula, Lingeswara Rao B, Tamil Arasi D. S. Low birth weight live births: An insight into placental pathology. JEMDS. 2015;4(16): 26452651.

[4]. Sanin LH, Lopez SR, Olivares ET, Silva MP, Carrilo ML. Relation between birth weight and placental weight. Biol Neonate. 2001;80: 113-7.

[5]. Habib FA. Prediction of low birth weight infants from ultrasound measurement of placental diameter and placental thickness. Ann Saudi Med. 2002;22(5-6):312-4.

[6]. Gunapriya Raghunath, Vijayalakshmi, Varsha Shenoy. A study on the morphology and the morphometry of the human placenta and its clinical relevance in a population in Tamil Nadu. Journal of Clinical and Diagnostic Research. 2011; Vol 5(2):282-286.

[7]. Hatti MA, Imran SS, Ashwini H. Effect of birth order on placental morphology and its ratio to birth weight. Int J Biol Med Res. 2013;4(1): 2765-71.

[8]. Rupa L Balihallimath et al., Placental Morphometry Determines the Birth Weight. Journal of Clinical and Diagnostic Research. 2013;7(11):2428-2431.

[9]. Ghodke S, Dharwadkar S. Hypertensive disorders affecting the morphometry of placenta. Journal of Scientific Society. 2012;39:17-18.

[10]. Londhe, Pradeep S.; Mane, Abhay B. Placental Morphometry in Relation to Birth Weight of Full Term Newborn Babies. National Journal of Integrated Research in Medicine. 2012;3(1):pp67.

[11]. R.D. Virupaxi, B. R. Potturi , V. S. Shirol, Desai S. P, V. B. Hukkeri. Morphology of Placenta and its Relation with Small for Date Babies in 950 Live Births. Recent Research in Science and Technology. 2011;3(2):123-12.

[12]. Little WA. The Significance of placental/weight ratios. Am J Obstet Gynecol. 1960;79:134-137.

How to cite this article: Divya Shanthi D'Sa, Sangeetha V. MORPHOMETRIC STUDY OF PLACENTA IN RELATION TO BIRTH WEIGHT OF FULL TERM NEWBORNS. Int J Anat Res 2018;6(1.2):4924-4927. DOI: 10.16965/ijar.2017.508 